\title{
Determination of the antioxidant potential of seaweed extracts using different methods
}

\author{
A. M. O’Sullivan ${ }^{1}$, Y. C. O’Callaghan ${ }^{1}$, M. N. O’Grady ${ }^{1}$, S. Kraan ${ }^{2}$, J. P. Kerry ${ }^{1}$ and N. M. O’Brien ${ }^{1}$ \\ ${ }^{1}$ Department of Food and Nutritional Sciences, University College Cork, Cork, Republic of Ireland and \\ ${ }^{2}$ National Seaweed Centre, National University of Ireland, Galway, Republic of Ireland
}

The marine environment is a relatively unexploited source of antioxidants and other potential functional ingredients that may be incorporated into foods in order to enhance their health benefits and thereby their commercial value. Marine-derived seaweeds and algae yield a wide range of antioxidant extracts with varying extents of activity ${ }^{(1)}$. The objective of the present study was to measure the antioxidant activity of extracts from several seaweeds harvested from the Irish coastline. Seaweeds were harvested, milled and subjected to a $60 \%$ (v/v) methanol extraction followed by solvent evaporation and freeze-drying. The total phenol content (TPC) of the samples was measured using the Folin-Ciocalteu method; results were expressed relative to gallic acid. The $\beta$-carotene bleaching assay (BCBA) measured the ability of the extracts to protect against the degradation of $\beta$-carotene at $50^{\circ} \mathrm{C}$ with time; results were expressed relative to a negative control. The 2,2-diphenyl-2-picrylhydrazyl hydrate-scavenging assay (DPPH) measured the ability of the extracts to scavenge DPPH radicals and the ferric-reducing antioxidant-potential assay (FRAP) measured the ability of the extracts to inhibit the reduction of a ferric compound to a ferrous compound relative to an ascorbic acid control.

\begin{tabular}{|c|c|c|c|c|c|c|c|c|c|c|c|c|c|c|c|c|}
\hline & \multicolumn{2}{|c|}{$\begin{array}{c}\text { Ascophyllum } \\
\text { nodosum }\end{array}$} & \multicolumn{2}{|c|}{$\begin{array}{l}\text { Laminaria } \\
\text { hyperborea }\end{array}$} & \multicolumn{2}{|c|}{$\begin{array}{c}\text { Laminaria } \\
\text { digitata }\end{array}$} & \multicolumn{2}{|c|}{$\begin{array}{c}\text { Himanthalia } \\
\text { elongata }\end{array}$} & \multicolumn{2}{|c|}{$\begin{array}{c}\text { Pelvetia } \\
\text { canaliculata }\end{array}$} & \multicolumn{2}{|c|}{$\begin{array}{c}\text { Fucus } \\
\text { vesiculosus }\end{array}$} & \multicolumn{2}{|c|}{$\begin{array}{c}\text { Saccharina } \\
\text { lattissima }\end{array}$} & \multicolumn{2}{|c|}{$\begin{array}{c}\text { Fucus } \\
\text { serratus }\end{array}$} \\
\hline & Mean & $\mathrm{SE}$ & Mean & $\mathrm{SE}$ & Mean & SE & Mean & SE & Mean & $\mathrm{SE}$ & Mean & SE & Mean & SE & Mean & SE \\
\hline Yield & 99.0 & 8.7 & 123 & 5.0 & 15.0 & 1.5 & 73.3 & 4.2 & 110 & 18.7 & 146 & 15.0 & 93.7 & 8.4 & 130 & 7.0 \\
\hline TPC (gallic acid equivalent) & 0.89 & 0.01 & 0.35 & 0.10 & 0.45 & 0.12 & 0.60 & 0.14 & 0.87 & 0.04 & 0.72 & 0.20 & 0.57 & 0.13 & 1.04 & 0.30 \\
\hline FRAP ( $\mu$ м ascorbic acid) & 81.4 & 6.1 & 25.6 & 3.9 & 60.5 & 4.6 & 46.7 & 4.5 & 57.7 & 10.5 & 110 & 17.7 & 17.2 & 2.8 & 113 & 18.5 \\
\hline DPPH (\% radical scavenging) & 25.6 & 1.9 & \multicolumn{2}{|c|}{ nd } & \multicolumn{2}{|c|}{ nd } & \multicolumn{2}{|c|}{ nd } & 4.1 & 3.5 & 31.2 & 3.2 & \multicolumn{2}{|c|}{ nd } & 5.5 & 1.8 \\
\hline BCBA ( $\%$ protection) & 76.3 & 3.6 & 41.7 & 9.5 & 62.2 & 1.7 & 1.2 & 2.8 & 53.9 & 1.2 & 71.2 & 3.8 & 33.9 & 2.3 & 62.2 & 1.9 \\
\hline
\end{tabular}

Values are means for four individual experiments. nd, Not detected.

The yield from the seaweed extraction process varied between samples from a dry weight of $15 \mathrm{mg}$ (L. digitata) to $146 \mathrm{mg}$ (F. vesiculosis). Samples were reconstituted in $10 \mathrm{ml}$ water and the antioxidant activity was determined employing each of the selected methods. Phenolic compounds constituted a major proportion of the antioxidant content of all plants including seaweeds. In the present study the total phenol content of the seaweeds ranged from $0.35 \mathrm{mg} / \mathrm{ml}$ (L. hyperboea) to $1.04 \mathrm{mg} / \mathrm{ml}(F$. serratus) and correlated with the antioxidant activity as measured by the FRAP assay $\left(R^{2} 0.6\right)$. However, the antioxidant activity as measured by the DPPH assay and the BCBA did not correlate with the phenol content, suggesting the presence of additional antioxidants such as ascorbic acid, aromatic amines and S-containing compounds in the extract as previously observed for wheat ${ }^{(2)}$. There was also no evident relationship between the dry weight and the antioxidant activity of the extracts. The DPPH assay was the least sensitive assay as it did not detect any antioxidant activity in several of the samples. In conclusion, A. nodosum, $F$. vesiculosis and $F$. serratus displayed the greatest antioxidant activity as measured by the methods employed in the present study and their potential health benefits deserve further investigation.

1. Devi KP, Suganthy N, Kesika P et al. (2008) BMC Complement Altern Med 8, 38-49.

2. Yu L, Haley S, Perret J et al. (2002) J Agric Food Chem 50, 1619-1624. 